\title{
Countering Entropy in The Crying of Lot 49 with Reader Involvement: Remedios Varo as a Role Model for Oedipa Maas
}

\author{
William Day
}

- In memory of The MC5 and American Ruse. Stasis is the precursor of entropy.

The Crying of Lot 49 is often relegated to a sort of secondary status within Thomas Pynchon's novelistic production. It has been highly criticized for its lack of resolution, and students reading it were said to fall into one of two groups: "those who hated the novel, and those who hated it a lot." And yet, its manageable size and tightly (dis)organized focus make it the most accessible of Pynchon's novels, if not the best understood. To a great extent, failure to understand the novel is the result of insufficient reader involvement. Pynchon requires far more from us than careful reading, he compels us as readers to go outside the novel and in this way participate actively in its construction. Entropy is frequently addressed by the author in his short stories and novels, and receives particular attention in Lot 49 . Could reader input possibly serve to counterbalance entropy? Are we as readers expected to participate actively in the construction of Thomas Pynchon's work and in so doing enable its uniqueness? The input of additional effort required on the part of the reader in researching areas for proper understanding of the novel may well be Pynchon's way of combating the entropic nature of communication. Typically, Pynchon never overtly tells the reader to look outside the confines of the novel. The act of reading Lot 49 therefore proves either a highly exhilarating or deeply stressful experience, depending on the type and extent of reader involvement.

Constructed and scripted in the guise of a detective story, it comes as no surprise that the key to unlocking the mystery is presented early on and is clearly stated. After introducing Oedipa and her disk jockey husband, Wendell Mucho Maas, Pynchon offers background on Oedipa's relationship with former lover Pierce Inverarity, now deceased, and of whose estate she has been named executrix:

And [Oedipa] had also gently conned herself into the curious, Rapunzel-like role of a pensive girl somehow, magically, prisoner among the pines and salt fogs of 
Kinneret, looking for somebody to say hey, let down your hair. When it turned out to be Pierce she'd happily pulled out the pins and curlers and down it tumbled in its whispering, dainty avalanche, only when Pierce had got maybe halfway up, her lovely hair turned, through some sinister sorcery, into a great unanchored wig, and down he fell, on his ass. But dauntless, perhaps using one of his many credit cards for a shim, he'd slipped the lock on her tower door and come up the conchlike stairs, which, had true guile come more naturally to him, he'd have done to begin with. But all that had then gone on between them had really never escaped the confinement of that tower. In Mexico City they somehow wandered into an exhibition of paintings by the beautiful Spanish exile Remedios Varo: in the central painting of a triptych, titled "Bordando el Manto Terrestre," were a number of frail girls with heart-shaped faces, huge eyes, spun-gold hair, prisoners in the top room of a circular tower, embroidering a kind of tapestry which spilled out the slit windows and into a void, seeking hopelessly to fill the void: for all the other buildings and creatures, with all the waves, ships and forests of the earth were contained in this tapestry, and the tapestry was the world. (20-21)

Coming, as it does, so early in the novel, the reader is likely to overlook what constitutes the novel's real theme. What elicits Oedipa's reaction on viewing the central panel of the Remedios Varo triptych "Bordando el manto terrestre"? The answer is that Oedipa Maas is nothing less than the novelistic projection of the heroines of Remedios Varo, who are in turn the artistic alter egos of the exiled Spanish painter. Oedipa is brought to tears by the central personage in the triptych because she identifies completely with the heroine, as well as with situations revealed in Varo's other paintings which logically would have been displayed in the same exhibition to which Pynchon refers. The author's dissatisfaction with his publisher at the publishing of Lot 49 is common knowledge, and it has been suggested the novel was hastily thrown together to meet the terms of Pynchon's contract. All that may well be, but Pynchon shows a stroke of genius in appropriating the person and artistic personages of Remedios Varo with their multifaceted eccentricities for use in fashioning the character of Oedipa Maas, the only fully developed figure in the novel, much in the same tradition of the "ready made" art objects of French surrealist Marcel Duchamps.

Oedipa, perverse, had stood in front of the painting and cried. No one had noticed; she wore dark green bubble shades. For a moment she'd wondered if the seal around her sockets were tight enough to allow the tears simply to go on and on and fill up the entire lens space and never dry. She could carry the sadness of the moment with her that way forever, see the world refracted through those tears, those specific tears, as if indices as yet unfound varied in important ways from cry to cry. She had looked down at her feet and known, then, because of a painting, that what she stood on had only been woven together a couple of thousand miles 
away in her own tower, was only by accident known as Mexico, and so Pierce had taken her away from nothing, there'd been no escape. What did she desire to escape from? Such a captive maiden, having plenty of time to think, soon realizes that her tower, its height and architecture, are like her ego only incidental: that what really keeps her where she is is magic, anonymous and malignant, visited on her from outside and for no reason at all. Having no apparatus except gut fear and female cunning to examine this formless magic, to understand how it works, how to measure its field strength, count its lines of force, she may fall back on superstition, or take up a useful hobby like embroidery, or go mad, or marry a disk jockey. If the tower is everywhere and the knight of deliverance no proof against its magic, what else? (21-22; emphasis added)

"Bordando" refers of course to the act of embroidering, but in most languages, by extension, it also refers to a complicated fabrication of halftruths and untruths. As the novel unfolds, Oedipa becomes entangled and lost in the weave of her own investigation. Instead of elucidating, her efforts at detective work produce only greater and greater layers of investigation, more and more foci and the labyrinth grows and grows: "Though she (Oedipa) saw Mike Fallopian again, and did trace the text of The Courier's Tragedy a certain distance, these follow-ups were no more disquieting than other revelations which now seemed to come crowding in exponentially. [. . .] As if the more she collected the more would come to her, until everything she saw, smelled, dreamed, remembered, would somehow come to be woven into the Tristero" (81; emphasis added).

In Entropy: A New World View, published some fifteen years after Lot 49, Jeremy Rifkin explains the reason for this confusion:

There is still another way to view the second law [of thermodynamics], the most profound way of all. The Entropy Law is also a statement that all energy in an isolated system moves from an ordered to a disordered state. [. . .] It must be emphasized that whenever the entropy increase is reversed in one place, it is only done by increasing the overall entropy of the surrounding environment. (43)

Akin to the advice the Red Queen gives to Alice in Alice in Wonderland, "Hereabouts it takes all the running you can do to keep in the same place. If you want to get somewhere else, you must run at least twice as fast" (Act Two, Scene 3: The Garden Path 66), the more Oedipa (and the reader) delves into the estate and legacy of Pierce Inverarity and explores the Tristero, the greater becomes the resulting entropy and confusion.

"Bordando el manto terrestre" is the name of the central panel of the triptych. Pynchon purposely limits his comments to this tableau, because the bracketing first and third panels provide additional information that immediately reveals the course and plot of the novel. In the same way Pynchon 
elaborates on the clever forgeries of texts (The Courier's Tragedy) and artifacts (US postage stamps), he also "forges" (both by omission and also by deliberate misrepresentation) the true meaning of the Remedios Varo paintings that drive Lot 49 from start to finish. (See endnote for Remedios Varo websites.)

Pynchon's subterfuge may seem quite unfair, breaking faith as it does with novelistic and particularly detective story tradition which has the reader placing his trust in the author to impart all information necessary for the reader to follow the action, understand its message, and finally solve the crime. But such sleight of hand (or pen) is precisely what makes reading Thomas Pynchon both a mindless pleasure and a challenging (although frustrating) intellectual experience. Pynchon leaves a breadcrumb trail of clues, à la Hansel and Gretel, but we must go outside the author's text if we are to fully appreciate Oedipa's situation. Further into the novel, Pynchon specifically equates Oedipa's role with that of a classic detective: "Where was the Oedipa who'd driven so bravely up here from San Narciso? That optimistic baby had come on so like the private eye in any long-ago radio drama, believing all you needed was grit, resourcefulness, exemption from hidebound cops' rules, to solve any great mystery. But the private eye sooner or later has to get beat up on" (124). As we shadow Oedipa's progress in attempting to resolve the enigma of Pierce Inverarity's estate and resulting legacy, we as readers function in much the same capacity. In retrospect, we can't say that we weren't warned.

The left-hand or first panel of Remedios Varo's triptych is titled Hacia la Torre, 'Toward the Tower,' and provides additional details. In her engaging and masterful biography Remedios Varo-Unexpected Journeys, Janet Kaplan explains it thus:

Varo shows her self-portrait character as one of a group of identical uniformed girls bicycling away from a beehive tower in which they were being held captive. Led by a "Mother Superior" figure and by an ominous man from whose bag fly birds that hover overhead as a guardian cordon ... The tone may be somber, but she laced her painting with whimsy, inventively constructing the girl's bicycles from the stiffened materials of their own clothing. She also championed independence, placing in the first row of the group mesmerized by its leaders a girl who rebels, her gaze reaching out defiantly, resisting what Varo termed "the hypnosis." (18)

Much of the interest and value of Lot 49 is the result of Oedipa Maas' transition from the role of domestic housewife, attendee at Tupperware and fondue parties and young Republican to the intrepid traveler on an unexpected journey, a scenario literally lifted from the art of Remedios Varo. Kaplan continues:

In the central panel of the autobiographical triptych, Embroidering Earth's Mantel / Bordando el manto terrestre, Varo offered a closer look at the life of a convent 
student. The same young girls, here captive in a tower, work as in a medieval scriptorium, embroidering the mantle of the world according to the dictates of a "Great Master." This hooded figure reads from the catechism of instructions while stirring a broth boiling in the same alchemical vessel from which the girls draw their embroidery thread. Each girl works alone, embroidering images onto a continuous fabric that spills out from the table-height battlements around the facets of the tower. Together they create a landscape with houses, ponds, streams, boats, animals and humans, all nestled within the folds of the fabric. Theirs is the traditional work of the convent, where needlework was deemed a skill appropriate for cultured young women....

Characteristically, Varo treated such tradition with irony. Among the girls working diligently, each at her own table, guarded by a comical veiled figure who lurks in the background playing a flute, Varo's rebellious heroine has "embroidered a trick in which one can see her together with her lover," their rendezvous subtly visible in a rendering hidden upside-down with the folds that flow from her table. In a masterful variant on the myth of creation, she has used this most genteel of domestic handicrafts to create her own hoped-for escape. Unlike Rapunzel and the Lady of Shalott, Varo's young heroine imprisoned in the tower is not merely a metaphor for confinement, but also an agent of her own liberation. To free herself from the strict academic tradition of faithfully recreating nature according to preordained rules and from the anonymity of being one among an indistinguishable many (all the girls have the same face), she connives to flee the tower that isolates her from the very life she is expected to create." $(19,21)$

The angst and shared frustration Oedipa experiences on viewing the central panel has its outward manifestation in the tears welling up behind her bubble shades. It should be noted that Oedipa's initial reaction is that of identifying her current status in life with Remedios Varo's heroines and it may also reflect postmodernist angst, since she accompanied Pierce to the exhibition and of course was not occupied with the details of his "legacy" at the time. Kaplan summarizes the final panel of the triptych as follows:

The title of the third panel, The Escape / La Huida, attests to her success. Here she is shown with her lover fleeing to the mountains. Again, fantasy builds on autobiography. Varo did escape at the age of twenty-one in 1930, by marrying Gerardo Lizarraga, a fellow artist, whom she had met while both were attending the Academia de San Fernando in Madrid. In Varo's fanciful depiction, the couple flees in a magical vehicle that looks like a furry inverted umbrella floating on a foggy mist. Their capes billow out behind them, catching the wind and acting as sails. This vehicle is one of many that she created, each differing in design from the others but all bearing the Varo touch of fantastic yet plausible detail. (23) 
Varo's triptych is clearly optimistic: Varo's rebellious heroine has escaped the confines of the tower with her lover and is free. In point of fact, the author lies to the reader when he writes: "there'd been no escape" (CL 21). Not only had there been escape, The Escape is the title of the third panel. By withholding mention of the first and third panels of the triptych, Pynchon prolongs the suspense of Oedipa's eventual escape from the tower of the central panel. Some twenty pages ahead, following her first tryst with the lawyer Metzger, Oedipa muses: "Things then did not delay in turning curious. If one object behind her discovery of what she was to label the Tristero System or often only The Tristero (as if it might be something's secret title) were to bring to an end her encapsulation in her tower, then that night's infidelity with Metzger would logically be the starting point for it; logically. That's what would come to haunt her most, perhaps: the way it fitted, logically, together. As if (as she'd guessed that first minute in San Narciso) things were revelation in progress all around her" (44).

The passage above refers to the oft-cited arrival of Oedipa in San Narciso. The technique of "mise en abime" generates a sense of disorientation and impending doom, and causes both the reader and Oedipa to pause and reflect on her state of mind. Pynchon maintains this same mood of prescience and foreboding throughout the entire novel. Also, despite Pynchon's admission "things were revelation in progress all around her," this revelation fails to reveal itself in any meaningful way to Oedipa or the reader and on the contrary heightens frustration and paranoia:

She drove into San Narciso on a Sunday, in a rented Impala. Nothing was happening. She looked down a slope, needing to squint for the sunlight, onto a vast sprawl of houses which had grown up all together, like a well-tended crop, from the dull brown earth; and she thought of the time she'd opened a transistor radio to replace a battery and seen her first printed circuit. The ordered swirl of houses and streets, from this high angle, sprang at her now with the same unexpected, astonishing clarity as the circuit card had. Though she knew even less about radios than about Southern Californians, there were to both outward patterns a hieroglyphic sense of concealed meaning, of an intent to communicate. There'd seemed no limit to what the printed circuit could have told her (if she had tried to find out); so in her first minute of San Narciso, a revelation also trembled just past the threshold of her understanding. Smog hung all around the horizon, the sun on the bright beige countryside was painful; she and the Chevy seemed parked at the centre of an odd, religious instant. As if, on some other frequency, or out of the eye of some whirlwind rotating too slow for her heated skin even to feel the centrifugal coolness of, words were being spoken. She suspected that much. She thought of Mucho, her husband, trying to believe in his job. Was it something like this he felt, looking through the soundproof glass at one of his colleagues with a 
headset clamped on and cueing the next record with movements stylized as the handling of chrism, censer, chalice might be for a holy man [. . .]? (24-25)

Additional clues both to Oedipa's character as well as to incidents in the novel and its ultimate denouement are provided by other Varo paintings probably included in the same exhibition viewed by Oedipa and Pierce in Mexico City.

Of Rupture / Ruptura (1955), Kaplan writes: "Reflecting on the break that she had found it necessary to make with the institutions and traditions of her past, she (Varo) depicted a cloaked and hooded figure descending a long flight of stairs, leaving a building from which dead leaves and old papers flutter" (23). This painting may have served as inspiration for the futility of Oedipa's "paper chase."

Sympathy / Simpatía (1955) is a likely source for the hair-spray incident in the bathroom of the Echo Courts motel as Oedipa prepares for the game of "Strip Boticelli" with Metzger. This all too bizarre tableau had to come from somewhere and the random action portrayal of uncontrolled objects and animals (cats) is a repeated motif in Varo's work. The incident serves to foreshadow Oedipa's zigzagging investigation of Pierce Inverarity's legacy and forewarns the reader that its progress, like the trajectory of the zooming hair-spray can, is beyond her ability to determine: "The can knew where it was going, she sensed, or something fast enough, God or a digital machine, might have computed in advance the complex web of its travel; but she wasn't fast enough" (37) The term "web" at first appears an odd choice, until we consider that a spider weaves its web, bringing us back to the initial metaphor of weaving or "embroidering earth's mantle / bordando el manto terrestre."

The Useless Science or The Alchemist (1955) repeats the theme of the author becoming the very subject of his composition, paralleling the possibility the deceased Pierce Inverarity has somehow constructed the entire paranoid universe that Oedipa seeks to resolve. Pynchon simultaneously casts doubt on this possibility when he says of Inverarity: "he'd slipped the lock on her tower door and come up the conchlike stairs, which, had true guile come more naturally to him, he'd have done to begin with" (20). This same concept is found in director of The Courier's Tragedy Randolph Dribblette's statement: "'You guys, you're like Puritans are about the Bible. So hung up with words, words. You know where that play exists, not in that file cabinet, not in any paperback you're looking for, but' - a hand emerged from the veil of showersteam to indicate his suspended head- 'in here. That's what I'm for. To give the spirit flesh. The words, who cares? They're rote noises to hold line bashes with, to get past the bone barriers around an actor's memory, right? But the reality is in this head. Mine. I'm the projector at the planetarium, all the closed little universe visible in the circle of that stage is coming out of my mouth, eyes, sometimes other orifices also"' (79; emphasis added). Oedipa dutifully notes in her memo book as "Under the symbol she'd copied off the latrine 
wall of The Scope into her memo book, she wrote Shall I project a world? If not project then at least flash some arrow on the dome to skitter among constellations and trace out your Dragon, Whale, Southern Cross. Anything might help" (82). Such statements support the premise that it is the role of the reader to determine what constitutes the reality of the novel.

About Varo's painting To Be Reborn (1960), Kaplan explains:

The setting is a sacred room deep within a forest. A woman again bursts through a wall, coming to her revelation in naked innocence, as if newly born [think "Birth of Venus" which parodies Oedipa's rebirth during the "Strip Boticelli" incident]. Looking into a chalice filled with liquid, she sees reflected not her face but a crescent moon. She is ecstatic, her eyes wide with wonder; for she has been allowed a secret wisdom - a glimpse of the Holy Grail allowed only to the initiated. It is as though the fertile vegetation of the room, the magic of the chalice, and the magnetic power of the moon have pulled her forth, releasing her from confinement. Varied legendary traditions link the moon with the realm of women's powers, and by associating this moment of psychic awakening with the lunar crescent and by emphasizing the character's nubile breasts, Varo presented this as essentially a female quest. This sense of a female vision pervades Varo's work. It informs her choice of symbols (the crescent moon reflected in the chalice, figures emerging out of vaginal slits surrounded by labial folds) and her depiction of the figures who experience psychic awakening as specifically female. Women are central to these compositions, and Varo makes their experience paramount, reflecting the personal quest for spiritual awareness that she herself had undertaken." (166-67)

Kaplan's evaluation ties in nicely with Lot 49 on several levels. The Paranoids' Serenade: "As I lie and watch the moon / On the lonely sea, / Watch it tug the lonely tide / Like a comforter over me, / The still and faceless moon / Fills the beach tonight / With only a ghost of day, / All shadow gray, and moonbeam white. / And you lie alone tonight, / As alone as l; / Lonely girl in your lonely flat, well that's where it's at, / So hush your lonely cry. / How can I come to you, put out the moon, send back the tide? / The night has gone so gray, l'd lose the way, and it's dark inside. ? No, I must lie alone, / Till it comes for me; / Till it takes the sky, the sand, the moon, and the lonely sea. / And the lonely sea ... etc. [FADE OUT]" (39-40). Oedipa's rebirth results from too many libations and she alone has the chalice: "'Come in,' she said [to Metzger], 'but I only have one glass.' 'I,' the gallant Metzer let her know, 'can drink out of the bottle."' (29)

Remedios Varo's heroines provide us with a ready-made portrait of Oedipa Maas. In fact, there is no physical description of Oedipa anywhere in the novel. Specifically, there are five references to shoes, which at first would appear arbitrary, but as the experienced reader of Thomas Pynchon's novels is aware, few if any details are ever arbitrary and none ever occur by 
happenstance. For instance, when Oedipa dines with her lawyer Roseman, he "tried to play footsie with her under the table. She was wearing boots, and couldn't feel much of anything. So, insulated, she decided not to make any fuss" (19); or when Oedipa visits Yoyodyne: "Heads came up at the sound of her heels, engineers stared until she'd passed, but nobody spoke to her" (84); or when Oedipa tracks the young W.A.S.T.E. mailman, she congratulates "herself on having thought to wear flats, at least" (130); or when she prepares to visit Emory Bortz: "Oedipa showered, put on a sweater, skirt and sneakers, wrapped her hair in a studentlike twist, went easy on the makeup" (148); or, lastly, when Oedipa finally realizes Pierce Inverarity is really dead and the "spell" is broken: "She turned, pivoting on one stacked heel, could find no mountains either" (177). The last reference is of particular importance and takes the reader back to Oedipa's first encounter with Remedios Varo's Embroidering the Earth's Mantle / Bordando el manto terrestre. The phrase "pivoting on one stacked heel" indicates both a radical change in course and direction-this is the moment Oedipa realizes the quest is over-and the multifarious details and false leads had perhaps been "stacked" against her.

Oedipa's lack of physical attributes (other than those "lent" by Remedios Varo's heroines) is deliberate, for she is everywoman-once again the object of the quest is also the means used to approach it. Also, Oedipa drinks copiously throughout the novel, which trait, while working well within the plot, may also be a tip of the hat to Exploration of the Sources of the Orinoco River (1959).

On Spiral Transit, Kaplan writes:

Similar travelers bound into vehicles of varying design appear, where they carefully navigate a spiraling course through the waterways of a medieval walled city. They, too, are embarked on a journey beyond the realm of mere navigation. As with the river explorer [Exploration of the Sources of the Orinoco River], theirs is a spiritual voyage, tracing the spiral of unfolding consciousness in eggshaped boats that resemble the vessels in which the alchemical transformation takes place. This entire composition is also remarkably similar to a Renaissance alchemical drawing of the Lapis Sanctuary, in which the tower at the center of the maze hides the Philosopher's Stone (a key element in alchemical transformation). Although it is possible that Varo might have come across a reproduction of this seventeenth-century Dutch rendering in her alchemical reading, it is more likely that such congruence of imagery (as with her visualizations of scientific speculations) reflects her intuitive understanding or (in terms closer to Varo's way of thinking) her magic envisioning of a phenomenon never seen. (169)

Oedipa Maas is reading book reviews in Scientific American at the start of Lot 49. This detail seems somewhat incongruous, given her attendance at Tupperware and fondue parties. The spiraling, circular construction of the 
novel is unmistakable-the novel ends with its very title, "Oedipa settled back, to await the crying of lot 49." She seems to have gotten nowhere. When she decides to "track down" the Tristero mail delivery system, she winds up back at her starting point, the house of John Nefastis. The Gl's bones return home to the USA from Italy to be used in the charcoal filters of cigarettes.

Even the most cursory comparison of the referenced Remedios Varo paintings and the painter herself shows a perfect overlapping with Oedipa. There results a transfer of character, personality and traits from Remedios Varo's paintings to Oedipa. The reader who has traveled outside the novel and viewed Remedios Varo's paintings will not be bothered in the least by the omission of details concerning Oedipa's past, since everything the reader needs to know in order to understand Oedipa's character and steadfast application in her search/quest is already present in Varo's work.

Central to the question of entropy in the novel is a machine invented by John Nefastis that purportedly contradicts the concept of entropy. Approximately halfway through the novel, Oedipa visits the inventor intent on learning whether or not she is a "sensitive." Nefastis explains the phenomenon to Oedipa in this way:

"Communications is the key," cried Nefastis. "The Demon passes his data on to the sensitive, and the sensitive must reply in kind. There are untold billions of molecules in that box. The Demon collects data on each and every one. At some deep psychic level he must get through. The sensitive must receive that staggering set of energies, and feed back something like the same quantity of information...."

"Entropy is a figure of speech, then," sighed Nefastis, "a metaphor. It connects the world of thermodynamics to the world of information flow. The Machine uses both. The Demon makes the metaphor not only verbally graceful, but also objectively true." (105-6)

Despite her best efforts, Oedipa cannot connect with the Demon, and leaves frustrated. The Demon is evoked again, near the end of the story, to demonstrate a lack of ability to transfer information. "But as with Maxwell's Demon, so now. Either she could not communicate, or he did not exist" (162).

Oedipa's lack of success with Maxwell's Demon serves as a metaphor for her similar lack of success at breaking the code and revealing the secret of the Tristero. In light of the open ending, with Oedipa awaiting "the crying of lot 49," the reader is literally back at the beginning of the novel, as paranoid and frustrated as Oedipa. The Demon also serves as metaphor for the reader's inability to resolve his/her reading of the novel in a satisfactory manner. Lot 49 offers multiple possible endings and an equal number of hypothetical interpretations or readings of the story. Readers and critics alike are divided on both plot (Communications Overload / The Whoring \& Narcissism of 
Southern California / Paranoia / Condemnation of American consumerism) and outcome (darkly pessimistic and negative / ambiguous — can't determine / hopefully optimistic but lacking proof).

If this were not enough, the reader still has to comprehend what constitutes the REAL meaning of Pynchon's novel, which derives its plot engine from the work of Remedios Varo whose inspiration can be traced back to the Spanish Golden Age.

Lot 49 is heavily invested with mythology. The feeling of "all the bits and pieces coated uniformly, like a salad of despair" (14) that Mucho Maas experiences with the defective used cars traded in at the lot where he worked might also refer to the reader's predicament on confronting a veritable salad of mythology and historical facts. There are classical references to Rapunzel, hieroglyphic sense of concealed meaning evoking Egyptians and other ancient rites, the Birth of Venus (a recurring artistic reference in Pynchon's work, first seen in $V$. and later in Gravity's Rainbow), Narcissus, passing through the Pony Express, the first USSR vs USA confrontation, and so forth.

Then, to our "salad of despair" are added references to the Southern California cultural landscape of the period, American cultural values in general, as well as a thorough discussion of the Scurvhamites, Jacobean revenge dramas, and the history of the postal service, from its inception to the present underground replacement in use by opponents to "their" regimented system. Pynchon introduces the reader to the concept of applied entropy and invites or rather compels the reader to assist in combating what Jeremy Rifkin claims to be the operational philosophy of the twentieth century by actively engaging in the construction of the novel. Instead of a simple explanation of the phenomenon of entropy, Pynchon transfers the very anxiety of entropy itself directly to the reader, who experiences the same existential angst as the heroine Oedipa.

Immediately following the religious moment and near revelation on arriving in San Narciso, Oedipa chooses by chance the "Echo Court." We are told that her dead lover Pierce Inverarity, had literally built the entire city, complete with its own freeway, in his own likeness. That's über narcissistic (Southern California's self-love is one of the plots advanced by some readers and critics). Greek mythology relates that Narcissus was such a handsome, self-absorbed young man that he literally fell in love with himself, and spent all his time admiring his own reflection. Among his admirers was a nymph who fell head over heels in love with him, but she could not compete with Narcissus' self-love, and so she slowly pined away, until all that was left was her name-Echo:

A representation in painted sheet metal of a nymph holding a white blossom towered thirty feet into the air; the sign, lit up despite the sun, said "Echo Courts." The face of the nymph was much like Oedipa's, which didn't startle her so much as a concealed blower system that kept the nymph's gauze chiton in constant 
agitation, revealing enormous vermilion-tipped breasts and long pink thighs at each flap. She was smiling a lipsticked and public smile, not quite a hooker's but nowhere near that of any nymph pining away with love either. (26-27)

A closer reading of the preceding paragraph provides the following information:

- The term "nymph" (Echo) occurs four times.

- The face of the nymph was much like Oedipa's.

- Like the nymph, Oedipa's breasts and legs are constantly appreciated throughout the novel.

- The nymph is wearing a gauze chiton ["a loose garment of varying length, similar to a tunic, worn by both men and women in ancient Greece" - Webster's]

- Her smile was ... nowhere near that of any nymph pining away with love.

Unlike Narcissus' nymph, Oedipa consummates her love with the narcissistic Metzer, child actor and now actor-turned-lawyer, where he acts in court. But instead of dying from love, the game of Strip Boticelli with Metzger, as we saw, liberates her (The Birth of Venus) and frees her from the tower, allowing her to proceed with The Escape (final panel of Remedios Varo triptych). Later, when Metzger deserts her and elopes for Las Vegas with Serge's "depraved 15-year-old girlfriend," the now liberated (that is, released from the tower) Oedipa shows a reaction of unusual strength: "No word to recall that Oedipa and Metzger had ever been more than co-executors. Which must mean, thought Oedipa, that that's all we were. She should have felt more classically scorned, but she had other things on her mind" (148).

The doppelgangers/role models of Remedios Varo and Echo come together with Oedipa's arrival: "in the Berkeley hills at a sprawling, manyleveled, German-baroque hotel, carpeted in deep green, going in for curved corridors and ornamental chandeliers.... The clerk took her to a room with a reproduction of a Remedios Varo in it, through corridors gently curving as the streets of San Narciso, utterly silent" (101). The presence of the Remedios Varo is another deliberate touch by Pynchon to take the reader back to the initial scene of Oedipa at the exhibition and to underline the relationship Oedipa $=$ Remedios Varo's heroine.

Given the upward spiral (Berkeley Hills), and the deep green (forest green?) carpet and curved (spiraled?) corridors, Oedipa is in fact climbing the mountain to attain spiritual self awareness, the journey evoked in the final panel of the triptych, The Escape. Later, at the same hotel, her dancing with the deaf-mutes would have been called an Anarchist miracle by Jesús Arrabal. (131). Oedipa first checks into the hotel and "escapes" from her 
metaphorical tower imprisonment a little more than halfway through the novel. She will use the rest of the novel to attempt to solve her quest for meaning.

Shortly prior to the end of the novel, Oedipa again finds herself alone, but this time her isolation is in fact liberation. Her mood may well coincide with that of the Remedios Varo heroine of Exploration of the Sources of the Orinoco River (1959). Kaplan writes,

The intrepid traveler is a most determined woman who bears particular resemblance to Varo herself. A courageous heroine, she has set out on a solitary journey to find "the source." Although she is dressed in a marvelously adapted English trench coat and bowler hat, carrying wings overhead that seem to have been borrowed from a theatrical production, the seriousness of her purpose is not compromised. The playfulness of her vehicle-a waistcoat transformed into a fragile little ship with notes in the side pocket [sound familiar?] and a compass instead of a watch fob [at the end of the novel, Oedipa is said "to have lost her bearings"] — does not negate the intensity of her expression nor the somber watchfulness of the dark birds that attend her from the hollows of nearby trees. What she confronts in a simple wineglass, set on a modest table in a hollowedout tree. A magical liquid flows out of the goblet, becoming the source of the river on which she travels. (168-69)

The beauty and magical attraction of Remedios Varo's paintings is that they always provide resolution that can be easily grasped by the viewer. In the case of Exploration of the Sources of the Orinoco River, the "intrepid traveler" has in fact journeyed to the source of the Orinoco River alone and succeeded in identifying that source, an overflowing wine glass. Much as the young girls in the tower, "bordando el manto terrestre" which will become the world and everything in it, and Oedipa viewing the painting, crying in despair until her tears fill up her eye sockets and the space behind the bubble shades, such solutions speak to our emotions, and provide a surrealistic, if not logical, solution. Like Remedios Varo's heroines, Oedipa, too, has embarked on a solitary, unexpected journey, the destination of which remains unforeseen:

They are stripping from me, she said subvocally-feeling like a fluttering curtain in a very high window, moving up to then out over the abyss ["mise en abime"] —-they are stripping away, one by one, my men. My shrink, pursued by Israelis, has gone mad; my husband, on LSD, gropes like a child further and further into the rooms and endless rooms of the elaborate candy house of himself and away, hopelessly away, from what has passed, I was hoping forever for love; my one extra-marital fella has eloped with a depraved 15-year-old; my best guide back to the Trystero has taken a Brody. Where am I? (153) 
And for a while, things appear even bleaker:

She (Oedipa) stood between the public [phone] and the rented car, in the night, her isolation complete, and tried to face toward the sea. But she'd lost her bearings. She turned, pivoting on one stacked heel, could find no mountains either. As if there could be no barriers between herself and the rest of the land. San Narciso at that moment lost (the loss pure, instant, spherical, the sound of a stainless orchestral chime held among the stars and struck lightly), gave up its residue of uniqueness for her; became a name again, was assumed back into the American continuity of crust and mantle. Pierce Inverarity was really dead. (177)

The added value of Remedios Varo's multiple and important contributions to the novel inform the character of Oedipa Maas and further enable her to overcome the Narcissus complex at Echo Courts. The strengthened and fortified personality of the heroine allows the reader to appreciate her triumph. Oedipa has, in fact, reached the summit of the magical mountain and completed her quest: "She (Oedipa) had dedicated herself, weeks ago, to making sense of what Inverarity had left behind, never suspecting that the legacy was America" (178).

In this sense, the ending of the novel is only mildly ambiguous. Oedipa is ready for the outcome, whatever it may be. The way the novel ends, restating its title, is a source of great frustration for many, who point out that we are literally back at the start of the novel. Not so. The circular nature of the final sentence "Oedipa sat back to await the crying of lot 49," is just another in a long series of circular references in the novel, as in Varo's Spiral Transit. What is important to see is that with each lap of the circuit, the traveler increases in experience and spiritual enlightenment.

The dissatisfaction evoked by readers with Pynchon's failure to end the novel properly, and his failure to provide an explanation of the enigma of the Trystero indicates a basic misreading of the novel itself, which has little to do with solving a detective type mystery and everything to do with the epic journey of self-awareness. Kaplan writes of the

sense of a female vision [that] pervades Varo's work. It informs her choice of symbols (the crescent moon reflected in the chalice, figures emerging out of vaginal slits surrounded by labial folds) and her depiction of the figures who experience psychic awakening as specifically female. Women are central to these compositions, and Varo makes their experience paramount, reflecting the personal quest for spiritual awareness that she herself had undertaken. (166-67)

Like the journeys of Remedios Varo's heroines, Oedipa's unexpected journey is a quest for spiritual awareness and self-knowledge. This sacred mission also explains the virtual absence of the "F-word" in Lot 49. In fact, there are 
very few occurrences of what appears to be Pynchon's favorite American vocabulary item in Gravity's Rainbow, and both are obscured or hidden. The first is in the reversed call letters of the radio station where Mucho is a disk jockey-"KCUF"-most appropriate given the sublimated sexual urges of the station's musical message. The second is the name of the publisher of The Courier's Tragedy, Da Chingado, which we may take as "screwed" which again is most appropriate for Oedipa's condition given her fruitless research on the text.

Such a spiritual journey also evokes Cervantes' Don Quixote, when the Don advises Sancho Panza, "has de poner los ojos en quien eres, procurando conocerte a ti mismo, que es el más difícil conocimiento que puede imaginarse" ("you have to look at who you are, trying to know yourself, which is the most difficult knowledge that can be imagined") (2.42).

To conclude, additional reader input is required to achieve adequate understanding of Oedipa's state of mind at the denouement, a term which is in fact inappropriate, because there is no "unknotting" of the story. We, as readers, cannot change the text. As Dribblette said: "Puritans, hung up on words." But our input does, in a sense, counteract the latent entropy that results from such a rich text. As elected readers of Pynchon we participate actively in the final construction of the novel, with all the rights and privileges attached thereto. Perhaps Thomas Pynchon has reserved a special award for the close reader, much as we give pets a special treat after they perform a clever trick. "'Your fly is open,' whispered Oedipa. She was not sure what she'd do when the bidder revealed himself" [Mindless Pleasure] (183).

Over the course of the novel, Pynchon has introduced the reader to the wondrous, haunting, surrealistic world of Remedios Varo and provided opportunity, encouragement and motivation for introspection and selfexamination of values. Oedipa is caught in the vortex of this introspection and the reader is invited to accompany her on the journey. Only in one Varo painting, Exploration of the Sources of the Orinoco River, does the (female) quester find the goal (and a surprising one at that). The goal is not what matters, only the journey.

_University of Louisville

\section{Works Cited}

Carroll, Lewis. Alice in Wonderland and Through the Looking Glass. London: Oberon Books, 2001.

Cervantes, Miguel de. Don Quijote de la Mancha. Barcelona: Editorial Juventud, 1958. Kaplan, Janet. Remedios Varo- Unexpected Journeys. New York: Abbeville Press, 2000. Pynchon, Thomas. V. New York: Harper Perennial, 1963.

. The Crying of Lot 49. [1966] New York: Harper \& Row, 1990. 
- Gravity's Rainbow. London: Jonathan Cape, 1974.

Rifkin, Jeremy. Entropy: A New World View. New York: McGraw-Hill, 1980.

Webster's New World Dictionary. New York: Collins-World, 1978.

Websites devoted to Remedio Varo y Uranga:

http://www.angelfire.com/hiphop/diablo4u/remedios.html http://www.honmex.com/eros/varo/varo8.htm http://www.hungryflower.com/leorem/varo.html (contains many links to other sites) http://www.turingmachine.org/remedios/expo.html 